\title{
Recent Development of Wiki Applications in Collaborative Writing
}

\author{
Shokoufeh Ansarimoghaddam (Corresponding author) \\ Department of English, Faculty of Modern Languages and Communication, University Putra Malaysia (UPM), 43300 \\ UPM Serdang, Selangor, Malaysia \\ Email: Shokoufehansari@gmail.com \\ Bee Hoon Tan \\ Department of English, Faculty of Modern Languages and Communication, University Putra Malaysia (UPM), \\ Malaysia \\ Email: tanbh@ fbmk.upm.edu.my \\ Mei Fung Yong \\ Department of English, Faculty of Modern Languages and Communication, University Putra Malaysia (UPM), \\ Malaysia \\ Email: yong@ fbmk.upm.edu.my \\ Zalina Mohd Kasim \\ Department of English, Faculty of Modern Languages and Communication, University Putra Malaysia (UPM), \\ Malaysia \\ Email: zalina@fbmk.upm.edu.my
}

\begin{abstract}
Wiki is increasingly gaining popularity in language learning. Some researchers suggest that wiki is a useful tool that enhances collaboration among students. Moreover, collaborative writing through wiki is an effective strategy for improving students' writing skills. This review summarizes findings of empirical research studies on the application of wiki in collaborative writing from 2005 till 2011. Some directions for future research related to the use of wiki for collaborative writing are also suggested.
\end{abstract}

Index Terms - wiki, collaboration, collaborative writing, empirical studies, ESL/EFL

\section{INTRODUCTION}

Among the four language skills, writing is the most important. It is believed that writing is a means for communicating, organizing, and developing of ideas (Alagoa \& Roberts, 2006) and is a major cognitive challenge (Kellogg, 2001). Moreover, it forces a powerful type of learning to take place (Ratcliffe, 2007). Although the importance of writing has been acknowledged, many EFL and ESL students are not competent in their writing skills and this has impacted on their academic progress. In order to improve students' writing skills, other strategies, besides having a competent writing teacher, should be considered, and using wiki for collaborative writing may be an effective one (Lin, 2005).

Collaborative writing involves more than one author to produce a written text. These authors can collaborate on all aspects of writing: content, structure, and language (Storch, 2005). Different research studies on L1 and L2 writing have demonstrated the usefulness of collaboration in promoting writing skills. Research conducted in L1 settings (e.g., Higgins, Flower \& Petraglia, 1992) has shown that collaborative writing is a good way to encourage reflective thinking, particularly when the learners need to explain and defend their ideas to their peers. Research on L2 writing also has demonstrated that the process of peer response or peer review helps language improvement at both micro and macro levels (e.g., Hu, 2005). Moreover, it is believed that collaborative writing promotes interaction and mutual support among co-workers (Chao \& Lo, 2009).

With technology advancement, computer-mediated communication (CMC) increases the chance of writing for students to communicate after class without time or location constraint. Online learning can be achieved through CMC open resources and tools so that learning is not confined to within an institution. To select a suitable CMC tool, the ease of using the tool is considered a critical criterion (Chao \& Lo, 2009). One easy to use CMC tool is wiki, designed and promoted by Cunningham in 1995. He offers a web space for using wiki in social interaction and collaboration (Godwin-Jones, 2005). Moreover, the application of wiki to support writing instruction is possibly the most general use of wiki (Lamb, 2004). 
In view of the perceived significance of wiki in recent studies, this paper reviews the empirical studies on wiki use in collaborative writing, and the objective of the paper is to address the question: What do empirical research studies conducted from 2005 to 2011 reveal about the extent of usefulness of wiki in collaborative writing?

The following sections present a brief discussion of wiki and its functions followed by the methodology, findings, and suggestions for future research.

\section{DEFINING WIKI}

The first wiki, with the name WikiWikiWeb, was developed in 1995 by Ward Cunningham. The software developer was from Portland, Oregon. Because Cunningham was dissatisfied with conventional word processing programs, he searched for a new documentation system that would better suit the needs of programmers. His goal was to create a relatively simple software that would enable collective work on software codes that could be published immediately (Ebersbach et al., 2008).

Today, wiki means a piece of software that permits users to freely create and edit the content of Web pages (Mak \& Coniam, 2008). "Wikiwiki" is a Hawaiian word that means "quick" or "hurry". The name shows the quick programming features of wiki. Content in wiki can be made available in a quick and uncomplicated manner. There are further developments of the first Wiki, such as MediaWiki, TWiki, Bitweaver, and ProWiki (Ebersbach et al., 2008).

Wiki can be used to collaboratively produce web pages that can be written and re-written multiple times by anyone, anytime, and anywhere with a computer connected to the Internet. All wikis also offer some technical core functions such as editing, links, history, recent changes, sandbox, and search functions. Employing wiki requires each paper linking to other papers, which can shape a new network structure and all previous versions or adjustments of any single page can be saved. Wiki offers instructions and introductions on its homepage to facilitate working with the system. Most wikis also offer a classic full-text or title search for wiki pages (Ebersbach et al., 2008).

\section{Methodology OF ReVIEW}

The data for this review paper were collected through online searches in reputable electronic databases. Since wiki is a quite a new technology, empirical research studies done on wiki applications in collaborative writing may have been initiated from 2005. Therefore, the searches were conducted to cover empirical studies published from 2005 to 2011. The journal e-databases consulted were the Education Resources Information Center (ERIC), Scopus, Science Direct, Springer Link, and Sage. The key words used for the searches were: wiki, collaboration, collaborative writing, application, ESL, EFL, and empirical study. The searches yielded a total of 686 articles. The abstracts of these articles were then examined to retain only studies that researched into both collaborative writing and wiki. Only 21 articles were found to be relevant and selected for the meta-analysis (see Appendix A). These papers were then read carefully to identify common themes. Two broad themes then emerged. The first was about wiki applications for collaborative writing, and the second was about the effects of collaborative writing on wiki.

\section{FINDINGS}

Previous researchers have investigated the use of wiki technology for different purposes. This review paper focuses on the different uses of wiki in collaborative writing. Findings from related studies are organized in two categories: (i) applications of wiki for collaborative writing, and (ii) effects of wiki for collaborative writing in English as first or second language contexts.

\section{A. Applications of Wiki in Collaborative Writing}

In reviewing the empirical research studies on wiki and collaborative writing, the following studies were identified and chosen that show various wiki applications for collaborative writing.

\section{Wiki for English for Specific Purposes}

A research study reports on how a wiki is applied in two tertiary-level ESP courses (Kovacic et al., 2007). The subjects were undergraduates at the University of Zagreb, Croatia. To conduct the study, two groups of student were chosen. One of the groups was 85 first-year students who attended an English Language course and another group was 28 second-year students who attended a Business English course. In the study various web-oriented learning activities (e-tivities) were used: Hotlist, Zip/unzip files, Brain Writing, Chain Letter, The Debate, and Storyboard. The results of the evaluation show a positive outcome of the wiki application and the helpfulness of most of the e-tivities studied.

\section{Wiki for Report Writing}

An empirical study was carried out to measure the knowledge of report writing by two groups of student in the first year Griffith University statistics class (Neumann \& Hood, 2009). The same data set from both groups was analyzed, but one group submitted the results by jointly writing a practice report with wiki and another group submitted the results in a practice report they wrote individually. The study found that both approaches enhanced report writing knowledge and did not vary much in the marks achieved when written reports were submitted for assessment later. There was no confirmation that the wiki used enhanced learning outcomes over and above related work conducted on an individual basis. The outcomes of the Neumann and Hood's (2009) study fall in between former reports of wholehearted success 
(e.g., Guzdial et al., 2001) and disappointing failure (Ebner et al., 2008) when wiki was applied to support students learning. Future research studies are required to show how individual preferences and the teaching context influence the effectiveness of wiki in educational applications.

Another study is a multi-literacy project that includes students collaboratively creating a multimodal information report applying the affordances of a wiki (Zammit, 2010). The study employed multiple cases using qualitative research techniques. Two primary classes, Years 5 and 4 (10 and 11years old), were chosen as subjects in the study. The findings show that the students' experience is very satisfying. The content, process of learning, and the application of technology were mentioned as the best aspects of the project.

The next related research is a case study done in a Hong Kong postsecondary institute (Coniam \& Kit, 2008). The study describes groups of learner who produced a report based on survey data they had gathered. In general, the project was successful in a way that groups produced better documents from groups who had worked with pen-and-paper. However, from this project some issues arose that need to be addressed for collaborative writing through wikis. The authors of the paper have mentioned two interesting points regarding using wikis: computer expertise and ability in English. Wiki is a user-friendly tool which requires slightly more expertise than using a word processor and an Internet browser. Moreover, in the study students' English language level was around IELTS level 4. This shows that the level of language proficiency cannot be an obstacle for using wiki. Wiki users should know that in order to use wiki appropriately, suitable tasks should be chosen to fit students' interests and language level.

\section{Wiki for Authentic Writing}

In a study on authentic writing through using wiki with Year 7 ESL learners in a secondary school in Hong Kong over a period of two months, students provided a description of their secondary school (Mak \& Coniam, 2008). The project is related to task-based approach to English language learning (Ellis, 1997) through a writing process. The writing in the study is considered authentic writing because the students' final drafts developed into a printed brochure of their 'new' school to be given to their parents. However, the data size was not sufficient to validate a higher generalizability of the research.

\section{Wiki for Collaborative Storytelling}

In a case study, wiki was used for storytelling by primary level students (Désilets \& Paquet, 2005). The researchers of the study aimed to investigate if and how young children could employ the wiki tool collaboratively to identify probable usability problems with the tool and to examine whether this sort of activity was interesting or not for girls as well as boys. Moreover, Désilets and Paquet wanted to see if non-linear narratives were simple to grasp by children at that age. The three collaboration modes employed in the study were co-located synchronous, co-located semisynchronous, and pair-editing. Three strategies for the division of labor were used in the research: random walk, pagebased and role-based. The results show that the teams of 2 to 5 students at the primary level can use wiki for collaborative web-based storytelling. The study provides insights into the collaborative process that children experience when using wiki for collaborative storytelling. It also reveals that both genders perform quite similarly in web-based storytelling. Future research studies can be conducted to reveal the complexity level of stories produced by wiki users. In addition, future research can investigate how existing activities can be modified in order to generate more engagement for wiki users.

Another study was conducted to propose a hypermedia approach to allow students to incorporate the episodes written by others to develop various branches of stories (Liu et al., 2011). The study examined how hypermedia and linear approaches influence the collaborative learning experience of 57 third graders with a mean age of 10 years at a suburban elementary school in Taipei. Linear and nonlinear approaches make developing stories easy in a completely different manner. Therefore, students' perceptions of hypermedia and linear approaches are different in their collaboration mechanisms. The findings show the superiority of the students' performance in the hypermedia group compared to the members in the linear group. The study reveals that a hypermedia approach can improve collaborative storytelling in social media and the improvement can be obtained by facilitating the collaborative process, ensuring a sense of authorship, and enhancing peer support of the stories. Remix and derivation are two strategies to support the creativity of work (Knobel \& Lankshear, 2008). One of the positive results of the study is that the design of social media can influence a child's tendency to use such strategies in collaborative storytelling. Future studies can be conducted to investigate how students at different ages and levels of study apply these two approaches in their collaborative storytelling experience.

\section{Wiki for Creating Electronic Books for Children}

In investigating advantages and limitations of using wiki in a foreign language course and to investigate participants ' perceptions on the quality and quantity of collaboration with wiki, a study was conducted with 17 university learners of intermediate Spanish (Moreno, 2009). The participants formed groups of 4-5 members. They were instructed to produce an electronic children's book in which the readers actively participated in the story plotline. In general terms, the wiki, in the form of a branching story, was proven to be a positive experience. As far as social and collaborative aspects of the project are concerned, it is found that although the majority of participants commented that they had worked well together in groups, many of them asserted a strong dislike for group work. The discomfort with working collaboratively in the project might be caused by the teacher who evaluated the participants' final product with only one grade for the 
group. Those participants who were more active in the project might have felt that the scoring system was not fair enough in evaluating each participant's contribution.

\section{Wiki for News Writing}

In a case study, a group of 23 undergraduate journalism students used wiki to write news reports together (Ma \&Yuen, 2008). The analysis of the student journalists' replies to the open-ended questions shows that revision is the central processing capability of wiki. The motivational factors to the revision through wiki include: accuracy, personal interest to the news topic, and story enrichment. The study shows that wiki is a unique learning environment that makes writing easy and it increases learning during the writing process. Wiki also provides a platform for individual learners to work alone and community members to interact with each other. When community members interact, they can learn much through revising each other's written work. The qualitative data shows that the learners valued the process and they had tried well to manage the complexity of shared editing.

\section{Wiki for Knowledge Sharing}

The ways an authentic learning community is made through wiki for advanced group collaboration and knowledge sharing were discussed in a research study conducted by Lin et al. in 2007. The participants were 51 freshmen from very diverse backgrounds. The participants had various roles in the experiment. They were required to submit their homework twice, before the midterm and after the midterm. Before the midterm, students submitted their individual work once every two weeks from September 2005 to January 2006. Then, they were divided into 10 groups based on their test scores. After the midterm, each group had to complete a game project. The results show that the method used in the study increased the participants' academic knowledge and peer support through using wiki.

\section{Wiki for Language Learning}

A ready-to-use wiki server, Sushiwiki, was used in a study that involved 43 college students in Taipei (Wang et al., 2005). The study aimed to investigate the wiki tool used in an English as a Second Language (ESL) course in Taiwan. Data on the students' usage and learning achievement was gathered and analyzed. The findings show that the wiki technology is naturally beneficial to learning. However, many factors were also present related to the use of wiki that inevitably remained uninvestigated. Therefore, more study is needed to explain new ways and approaches of using wiki.

\section{Wiki for Scaffolding Collaborative Writing among Students}

In a case study design, quantitative and qualitative data were used to investigate how wiki helped to scaffold L2 writers (Woo et al., 2011). The researchers of the study investigated the wiki's affordances in order to find out how they might assist in scaffolding students throughout their collaborative writing project. Results show that the application of wiki was perceived positively and in general, it was believed that wiki promoted teamwork and improved writing. The findings also show that wiki's key affordances facilitate students' collaborative engagement in creative problem solving and peer critiquing. This may have helped to scaffold students in using their critical thinking and creative reasoning skills during the analysis and evaluation of their writing to construct comments and revise based on their peers' comments. As a result, wiki may have helped to generate more creative content in the students' writing.

\section{Wiki for Effective Communication}

A study that was conducted with 14 students at Stockholm University focused on the application of wiki in the course on Effective Communication in English. In this course, wiki is employed to teach writing for academic and professional purposes (Kuteeva, 2011). The study aimed to analyze the impact of applying wiki on the writer-reader relationship, and the research techniques used are self-reporting questionnaire, participant observation, and text analysis. The results show that writing on the wiki can help to enhance students' awareness of audience which will result in more readeroriented texts. By using the wiki for writing activities, students seem to pay more attention to grammatical correctness and structural coherence. High uses of engagement markers (questions and commands, personal pronouns) by the students in their writing further confirm the extent of the writer-reader interaction. The paper also describes the way wiki can be applied in the teaching of traditional academic writing skills such as paragraph structure and text organization in a collaborative environment of learners.

\section{Wiki for Topical Writing}

Mediawiki was used in a study that involved 31 students in a high school in Norway (Lund, 2008). The researcher of the study investigated the kinds of interdependent activities that learners engaged in. Besides, the effect of wiki on collaborative work in a foreign language learning classroom was also investigated. The study shows a change in the students' viewpoints about learning processes from individualism to collective production. Moreover, the results show that wiki can be a practical instrument for supporting collective language skills.

\section{Wiki for Assessment}

In a research study comparing the effects of two peer assessment methods, 232 undergraduates were chosen through convenience sampling (Xiao \& Lucking, 2008). The research also investigated student satisfaction with peer assessment within a wiki environment. Validity and reliability of assessment scores were examined as well. The findings show that students in the experimental group had greater improvement in their writing than those in the comparison group, and students in the experimental group were more satisfied with the peer assessment method both in peer assessment structure and peer feedback. Furthermore, the findings show that the validity and reliability of student assessment scores were high. Providing an online collaborative learning environment and using wiki interactive software to facilitate peer 
assessment can enhance the value of peer assessment. The research provides rich implications for readers in relation to peer assessment method.

Another study examines the potential of applying wiki to increase teacher capabilities in teacher-education programs. The study was initiated in 2008. Later, the researchers conducted a second study in 2009. The second case study used the former study's design but with more participants (Lai \& Ng, 2011). Specifically, the study investigated what teachers are capable of learning in wiki-based activities, the possibility of integrating self-assessment and peer assessment with wiki-based activities, and whether wiki-based activities are an effective and successful means of developing teachers' capabilities. Findings show that the students mastered different skills throughout their collaborative activities and peer learning, such as collaboration skills, ICT skills, and organizational skills. Moreover, the study found that wiki-based activities gave teachers a new way of teaching that could be a superior alternative for traditional classroom-based learning. Researchers also found that assessment rubrics were a possible way to grade wiki sites and there was a need for change in the way teachers used assessments.

After reviewing the above research studies, several inferences can be made. Firstly, wiki is a useful tool that helps students take more responsibility of their own learning. Second, since wiki can be used anywhere and anytime, it can be used for various purposes. Third, although all the research studies discussed are empirical which are of great importance in determining the acceptability of a new tool, these studies have their own limitations. More studies on wiki need to be conducted with larger numbers of student. Fourth, in future studies on wiki the sequencing of tasks in the study should be considered. Fifth, the comparison of various tasks may reveal more applications of wiki for collaborative writing.

\section{B. Effects of Wiki on Collaborative Writing in English}

Researchers have conducted studies on the use of wiki to develop the writing of ESL/EFL learners and to considering the effects of wiki on peer correction, process writing, and synchronous interactions (Lin, 2005; Franco, 2008; Chao \& Lo, 2009; Kessler, 2009; Turgut, 2009; Elola \& Oskoz, 2010). The studies are discussed in the following sections.

\section{Effects of Wiki on Peer Correction}

The results of a study conducted in a college in central Taiwan show that collaborative writing with the use of wiki improves writing skill, increases awareness of the forms and functions of English language, and enhances contribution to peers (Lin, 2005). Moreover, the findings demonstrate that wiki can be a useful tool for lower proficiency students to learn and contribute more in writing processes. However, the study is a pilot and therefore requires further research to make convincing claims about the usefulness of wiki for collaborative writing.

Another study was conducted to investigate the relationship between wiki application and collaborative learning with the purpose of peer-correction and writing improvements (Franco, 2008). The study found that the students were interested to interact in an online community with a higher degree of motivation. The study also found increased opportunities related to writing and developing learners social skills. However, the study was carried out with a group of 18 Brazilian students only, and the findings are not generalizable to other age group, gender or geographic context.

In a study conducted by Kessler (2009), the aim was to determine the degree that participants initiated to correct their own and their peers' writing. Besides, the degree of accuracy that they achieved in their collaborative writing was determined. The researcher also investigated the students' attention to grammar revision versus content revision. Forty non-native pre-service teachers in a large Mexican university were observed in an online content-based course for 16 weeks. The purpose was to improve the teachers' language skills while they were studying about the cultures of the English-speaking world. The main part of the course was a wiki that was created, developed, and revised collaboratively throughout the course. The teacher candidates in the study mentioned that they liked to use such tasks in their own classes with perhaps an inclusion of teacher intervention. May be regular programs of using activities that focus on content and accuracy help students improve their accuracy in writing. More research studies should be conducted in order to validate the usefulness of wiki for improving accuracy in writing skill.

In another study conducted in a college in Turkey, the researcher used a specific wiki tool called PB wiki for commenting on essays and peer editing (Turgut, 2009). An analysis of 77 student compositions was discussed. The study produced three results: First, improvement in the students' writing skills; second, improvement in the students' sharing of ideas, confidence, and critical feedback; and third, motivation to take part in the activities.

All the above studies in this section seem to point to the various degrees of effectiveness of wiki on peer correction in collaborative writing.

\section{Effects of Wiki on Process Writing}

The instructional design of applying a wiki-based collaborative writing project that helps EFL learners to complete a collaborative writing task is a study that demonstrates how process-oriented writing can be enhanced and adapted for L2 learners (Chao \& Lo, 2009). The five-staged process used in Chao and Lo's study included: collaborative planning, partitioned drafting, peer-revising, peer-editing, and individual publishing. Procedural scaffolding and collective scaffolding were also employed to support the instructional design. Besides, three pedagogical principles were used in the study, namely, task-oriented learning, process-oriented teaching, and collaborative learning. The findings indicate a high percentage of students' satisfaction and show positive perceptions of using the wiki-based collaborative writing environment. The instructional design of applying the writing project helps EFL learners to complete a collaborative writing task with less time constraint. Besides, the instructional design offered in the study can be used as a useful guide for teachers and students. Although the study proposes a useful approach to the writing process for EFL learners and 
presents fruitful findings, it suffers from a shortcoming as well. In the study, data were collected through four questionnaires only including a 5-point Likert scale questionnaire and three open-ended questionnaires. The only data collection technique in the present study was questionnaire which does not add enough depth to the study.

\section{Effects of Wiki on Synchronous Interactions among Students}

Investigation was also carried out to explore L2 learners' approaches to the writing task on wiki by analyzing learners' individual and collaborative writing. Elola and Oskoz (2010) examined learners' synchronous interactions when they talked about the content, structure and other aspects of their writing tasks. Moreover, the perceptions of learners about individual and collaborative writing and their impressions of applying social tools in the first language writing class were investigated. Participants of the study were eight Spanish majors at a U.S. community mid-sized East Coast University. In the study, learners wrote two argumentative essays, the first one collaboratively and the second individually. Findings show that learners' interactions with the text varied when working individually or collaboratively. Further, an analysis of learners' approaches to group writing through applying social tools demonstrates that wiki and chat permit learners to focus on writing components in various manners based on whether they interacted in the wiki or on the chat. Although the study presents useful information, it has some limitations such as the small number of participants. Future studies should be done with more participants and better sequencing tasks that may affect the results should be considered.

Reviewing the empirical studies in this section leads to an informed view of how to use wiki for collaborative writing in order to achieve better results. To do so, first, students should be completely familiar with wiki before they start to write in groups. Second, for minimizing the possibility of students feeling discomfort about group members' corrections and comments on wiki, some face-to-face activities should be developed to acquaint students with their group members before using wiki; otherwise, students may become frustrated and hence cannot achieve the desirable results.

\section{CONCLUSION AND SUGgESTION FOR FutuRE RESEARCH}

In this paper, the empirical research studies conducted from 2005 to 2011 were discussed. The empirical research studies were organized into two categories: i) applications of wiki for collaborative writing, and ii) effects of wiki for collaborative writing in English as a second and first language context.

With regard to the application and effects of wiki for collaborative writing, results of various studies generally suggested that wiki can be considered a useful tool for learning, particularly language learning. Wiki provides an interest collaborative writing platform to online community and is a useful and effective tool for the improvement of students' writing skills. Moreover, the usefulness of wiki for peer collaboration and peer assessment were achieved in the reviewed studies. Besides, a high percentage of students' positive perception of using the wiki-based collaborative writing environment was found.

Despite positive findings, several limitations were present and should be considered in the research studies. First, the research found that the applications of wiki were limited to certain areas only. Second, the studies were conducted with small numbers of participant. Therefore, the results and findings cannot be generalized to other similar contexts. Third, most of the students in these studies used wiki for the first time. It meant that they were not familiar with wiki and the unfamiliarity might have affected the research result. Fourth, the duration of research is another limitation identified. Most of the research studies were conducted within a short period of time. If future studies can be conducted over a longer period of time, the results may be different. Consequently, the limitations might have influenced the achieved results.

The review of the empirical research studies can serve as a guide for teachers and students who are interested in using wiki for various pedagogical and learning purposes. This review can also be beneficial for researchers who are interested in conducting studies related to the use of wiki as it highlights recent studies done on wiki and provides some insights into potential areas that could be explored in the future.

Since wiki is relatively new and until now there is only a small body of research on different aspects of using it, more studies should be conducted to reveal more useful applications of wiki for collaborative learning and writing. Moreover, future research may investigate the effects of gender and culture of different students with various levels of proficiency. More studies with pre-test and post-test design should be conducted to confirm the usefulness of wiki for collaborative writing.

\section{APPENDIX A SUMMARY OF REVIEWED STUDIES}

\begin{tabular}{|l|l|l|l|l|}
\hline Study & Participants & Purpose of the Study & Type of Data & Findings \\
\hline $\begin{array}{l}\text { Désilets and } \\
\text { Paquet (2005) }\end{array}$ & $\begin{array}{l}\text { Primary level students } \\
\text { (grade4-6) used wiki for } \\
\text { collaborative story } \\
\text { telling. }\end{array}$ & $\begin{array}{l}\text { To investigate how young } \\
\text { children can use wiki for } \\
\text { collaboration, and to see if } \\
\text { the activity is equally } \\
\text { interesting for girls and boys. }\end{array}$ & Observation, wiki. & $\begin{array}{l}\text { Primary level students are able to use } \\
\text { wiki for collaborative web-based } \\
\text { storytelling. Guidelines were given to } \\
\text { help teachers apply wiki in classroom }\end{array}$ \\
\end{tabular}




\begin{tabular}{|c|c|c|c|c|}
\hline Lin (2005) & $\begin{array}{l}\text { EFL Learners studying } \\
\text { in central Taiwan } \\
\text { colleges. }\end{array}$ & $\begin{array}{l}\text { To investigate the } \\
\text { effectiveness of wiki for } \\
\text { collaborative writing. }\end{array}$ & $\begin{array}{l}\text { Survey, Interview, } \\
\text { Online discussion, } \\
\text { learning logs, and } \\
\text { reflective diary. }\end{array}$ & $\begin{array}{l}\text { Collaborative writing enhances writing } \\
\text { ability, promotes contribution to peers, } \\
\text { and increases awareness of the forms } \\
\text { and function of English. }\end{array}$ \\
\hline $\begin{array}{l}\text { Wang et al. } \\
(2005)\end{array}$ & $\begin{array}{l}43 \text { freshman level } \\
\text { students studied English } \\
\text { as a second language at a } \\
\text { public college in Taipei. }\end{array}$ & $\begin{array}{l}\text { To examine the application of } \\
\text { wiki in English as a second } \\
\text { language course. }\end{array}$ & $\begin{array}{l}\text { Web servers' } \\
\text { access log, wiki }\end{array}$ & $\begin{array}{l}\text { The wiki technology is "naturally" } \\
\text { beneficial to learning. }\end{array}$ \\
\hline $\begin{array}{l}\text { Kovacic et al. } \\
(2007)\end{array}$ & $\begin{array}{l}\text { Two groups: one group } \\
\text { with } 85 \text { first-year } \\
\text { students who learned } \\
\text { English language and the } \\
\text { other } 28 \text { second-year } \\
\text { Business English } \\
\text { students. }\end{array}$ & $\begin{array}{l}\text { To evaluate } \\
\text { e-tivities and the overall use } \\
\text { of the wiki. }\end{array}$ & $\begin{array}{l}\text { Evaluation, } \\
\text { Survey }\end{array}$ & $\begin{array}{l}\text { Positive outcome of the wiki and the } \\
\text { usefulness of most of the e-tivities . }\end{array}$ \\
\hline $\begin{array}{l}\text { Lin et al. } \\
(2007)\end{array}$ & $\begin{array}{l}\text { Freshman from very } \\
\text { diverse backgrounds and } \\
\text { roles. }\end{array}$ & $\begin{array}{l}\text { To investigate how an } \\
\text { authentic learning community } \\
\text { is constructed by wiki for } \\
\text { advanced collaboration and } \\
\text { knowledge sharing. }\end{array}$ & Observation & $\begin{array}{l}\text { The method raised the students' } \\
\text { knowledge and peer supports by using } \\
\text { wiki. }\end{array}$ \\
\hline Franco (2008) & $\begin{array}{l}18 \text { students from a } \\
\text { private language school } \\
\text { located in Brazil. }\end{array}$ & $\begin{array}{l}\text { To investigate the } \\
\text { relationship between wiki and } \\
\text { collaborative learning } \\
\text { focusing on peer-correction } \\
\text { and writing improvements. }\end{array}$ & $\begin{array}{l}\text { Writing and } \\
\text { comments posted } \\
\text { on a private wiki, } \\
\text { questionnaire }\end{array}$ & $\begin{array}{l}\text { The online community had a higher } \\
\text { degree of motivation. There was } \\
\text { increased opportunity related to writing } \\
\text { and developing learners' social skills. }\end{array}$ \\
\hline Lund (2008) & $\begin{array}{l}\text { EFL learners of Hillside } \\
\text { senior high school. }\end{array}$ & $\begin{array}{l}\text { To examine wiki for the } \\
\text { notion of collective zone of } \\
\text { proximal development and } \\
\text { sociogenesis. }\end{array}$ & $\begin{array}{l}\text { Wiki, Videotaped } \\
\text { transcripts of } \\
\text { learner interaction }\end{array}$ & $\begin{array}{l}\text { A shift in the students' perspectives } \\
\text { regarding learning processes from } \\
\text { individualism to collective knowledge } \\
\text { construction. Wiki is viable to support } \\
\text { collective language skills. }\end{array}$ \\
\hline $\begin{array}{l}\text { Ma and Yuen } \\
(2008)\end{array}$ & $\begin{array}{l}23 \text { undergraduate } \\
\text { journalism students. }\end{array}$ & $\begin{array}{l}\text { To investigate the process of } \\
\text { collaborative news writing } \\
\text { and learners' perceptions on } \\
\text { applying wiki. }\end{array}$ & $\begin{array}{l}\text { Open-ended } \\
\text { survey }\end{array}$ & $\begin{array}{l}\text { Wiki is a unique learning environment } \\
\text { that makes writing easy and increasse } \\
\text { learning during the writing process. } \\
\text { Wiki provides a platform for both } \\
\text { individual learners and community. }\end{array}$ \\
\hline $\begin{array}{l}\text { Mak and } \\
\text { Coniam } \\
(2008)\end{array}$ & $\begin{array}{l}\text { Year } 7 \text { ESL learners in a } \\
\text { secondary school in } \\
\text { Hong Kong. }\end{array}$ & $\begin{array}{l}\text { To investigation authentic } \\
\text { writing through using wiki. }\end{array}$ & $\begin{array}{l}\text { Qualitative and } \\
\text { quantitative data } \\
\text { through } 3 \text { stages. }\end{array}$ & $\begin{array}{l}\text { Impact is significant in two ways: the } \\
\text { task's real outcome (the brochure) } \\
\text { increased students' confidence as } \\
\text { writers and it taps students' creative } \\
\text { skills. }\end{array}$ \\
\hline $\begin{array}{l}\text { Xiao and } \\
\text { Lucking } \\
(2008)\end{array}$ & 232 undergraduates. & $\begin{array}{l}\text { To compare the effects of two } \\
\text { peer assessment methods and } \\
\text { to investigate students' } \\
\text { satisfaction with peer } \\
\text { assessment. }\end{array}$ & $\begin{array}{l}\text { Rubric for } \\
\text { academic papers, } \\
\text { survey } \\
\text { questionnaire, } \\
\text { comparing two } \\
\text { sets of rating score }\end{array}$ & $\begin{array}{l}\text { Students in the experimental group show } \\
\text { greater improvement in writing than the } \\
\text { comparison group. Findings indicate } \\
\text { that the validity and reliability of student } \\
\text { generated rating scores were high. Using } \\
\text { the Wiki interactive software and } \\
\text { providing an online collaborative } \\
\text { learning environment added value to } \\
\text { peer assessment. }\end{array}$ \\
\hline $\begin{array}{l}\text { Chao and Lo } \\
\text { (2009) }\end{array}$ & $\begin{array}{l}51 \text { L2 learners at a } \\
\text { university in central } \\
\text { Taiwan. }\end{array}$ & $\begin{array}{l}\text { To investigate process- } \\
\text { oriented writing among L2 } \\
\text { learners. }\end{array}$ & $\begin{array}{l}\text { Cross-referencing } \\
\text { open- ended } \\
\text { questionnaires, } \\
\text { descriptive } \\
\text { statistics. }\end{array}$ & $\begin{array}{l}\text { High percentage of student satisfaction } \\
\text { of applying wiki. } \\
\text { The instructional design of the project } \\
\text { with the five-stage writing process } \\
\text { helped EFL learners to complete a } \\
\text { collaborative writing task in less time. }\end{array}$ \\
\hline Kessler (2009) & $\begin{array}{l}40 \text { NNS pre-service } \\
\text { teachers from a large } \\
\text { Mexican university. }\end{array}$ & $\begin{array}{l}\text { To determine the degree that } \\
\text { participants correct their own } \\
\text { and peer correction. To } \\
\text { determine the degree of } \\
\text { accuracy and their attention to } \\
\text { grammar revision vs. content } \\
\text { revision. }\end{array}$ & Wiki, Interview & $\begin{array}{l}\text { Participants contributed in the form of } \\
\text { peer and self-editing. They considered a } \\
\text { web-based collaborative activity less } \\
\text { demanding. Overall tendency among } \\
\text { participants was to focus on meaning } \\
\text { rather than form. }\end{array}$ \\
\hline $\begin{array}{l}\text { Moreno } \\
(2009)\end{array}$ & $\begin{array}{l}17 \text { university learners of } \\
\text { intermediate Spanish } \\
\text { whose first language was } \\
\text { English. }\end{array}$ & $\begin{array}{l}\text { To create an electronic } \\
\text { children's book and to } \\
\text { investigate the learners' } \\
\text { perception on language gains } \\
\text { and group work success. }\end{array}$ & $\begin{array}{l}\text { Wiki, post-task } \\
\text { questionnaire }\end{array}$ & $\begin{array}{l}\text { The branching story in wiki shows } \\
\text { positive experience generally. Learners } \\
\text { were satisfied when they were able to } \\
\text { use the grammar learned in the project. } \\
\text { Majority said they had worked well in } \\
\text { groups, but some declared strong dislike } \\
\text { for group work. }\end{array}$ \\
\hline
\end{tabular}




\begin{tabular}{|c|c|c|c|c|}
\hline $\begin{array}{l}\text { Neumann and } \\
\text { Hood } \\
(2009)\end{array}$ & $\begin{array}{l}\text { First year Griffith } \\
\text { University statistics } \\
\text { class. }\end{array}$ & $\begin{array}{l}\text { To measure learning } \\
\text { outcome, knowledge of report } \\
\text { writing, attitude toward } \\
\text { statistics, engagement with } \\
\text { other students of two groups } \\
\text { of students. }\end{array}$ & $\begin{array}{l}\text { Wiki, } \\
\text { questionnaires }\end{array}$ & $\begin{array}{l}\text { Both approaches increased report } \\
\text { writing knowledge. } \\
\text { Wiki approach makes higher } \\
\text { engagement with other students. Student } \\
\text { engagement, not performance on } \\
\text { assessment, maybe increased when wiki } \\
\text { is used to support learning in higher } \\
\text { education. }\end{array}$ \\
\hline Turgut (2009) & $\begin{array}{l}77 \text { students of a college } \\
\text { preparatory writing } \\
\text { course in Turkey. }\end{array}$ & $\begin{array}{l}\text { To use wiki for peer editing } \\
\text { and for commenting an } \\
\text { essays. }\end{array}$ & $\begin{array}{l}\text { Wiki, open-ended } \\
\text { questions, } \\
\text { Semi-structured } \\
\text { interviews }\end{array}$ & $\begin{array}{l}\text { Improvements in the students' writing } \\
\text { skills } \\
\text { and sharing of ideas, critical feedback } \\
\text { and confidence. }\end{array}$ \\
\hline $\begin{array}{l}\text { Elola and } \\
\text { Oskoz (2010) }\end{array}$ & $\begin{array}{l}8 \text { Spanish majors at a } \\
\text { U.S. midsized east coast } \\
\text { university. They enrolled } \\
\text { in an advanced Spanish } \\
\text { writing course. }\end{array}$ & $\begin{array}{l}\text { To explore L2 learners' } \\
\text { approaches to the writing } \\
\text { tasks on wiki; to examine } \\
\text { learners' synchronous } \\
\text { interaction and to describe } \\
\text { learners' perception of } \\
\text { individual and collaborative } \\
\text { writing. }\end{array}$ & $\begin{array}{l}\text { Essay draft, } \\
\text { questionnaires, } \\
\text { wiki drafts and } \\
\text { chats }\end{array}$ & $\begin{array}{l}\text { Learners' interactions with the texts } \\
\text { differ when working individually or } \\
\text { collaboratively. Learners' approaches to } \\
\text { collaborative writing show that wiki and } \\
\text { chat allowed them to concentrate on } \\
\text { writing components differently. }\end{array}$ \\
\hline $\begin{array}{l}\text { Zammit } \\
(2010)\end{array}$ & $\begin{array}{l}\text { A Year } 5 \text { (11 years old }) \\
\text { class, and Year } 4 / 5(10 \\
\text { and } 11 \text { years old class). }\end{array}$ & $\begin{array}{l}\text { To involve students to work } \\
\text { collaboratively on wiki in a } \\
\text { multi-literacy project to } \\
\text { create multi-modal reports. }\end{array}$ & $\begin{array}{l}\text { Questionnaire, } \\
\text { interview }\end{array}$ & $\begin{array}{l}\text { Working with wiki gives opportunity for } \\
\text { students to engage with } 21^{\text {st }} \text { century } \\
\text { literacy practices. It provides an } \\
\text { alternative pedagogical practice in the } \\
\text { conventional curriculum. }\end{array}$ \\
\hline $\begin{array}{l}\text { Kuteeva } \\
(2011)\end{array}$ & $\begin{array}{l}14 \text { students (eight female } \\
\text { and six male). }\end{array}$ & $\begin{array}{l}\text { To investigate how the course } \\
\text { wiki was used to teach } \\
\text { writing for academic and } \\
\text { professional purposes, and to } \\
\text { analyze what impact the wiki } \\
\text { had on the writer- reader } \\
\text { relationship. }\end{array}$ & $\begin{array}{l}\text { Participant } \\
\text { observation, text } \\
\text { analysis, } \\
\text { self-report } \\
\text { questionnaire }\end{array}$ & $\begin{array}{l}\text { Writing on the wiki can contribute to } \\
\text { increasing awareness of the audience } \\
\text { and enhancing the use of interpersonal } \\
\text { meta discourse. }\end{array}$ \\
\hline $\begin{array}{l}\text { Lai and Ng } \\
\text { (2011) }\end{array}$ & $\begin{array}{l}\text { First group: students } \\
\text { from full-time } \\
\text { Postgraduate Diploma in } \\
\text { Education (Secondary); } \\
\text { second group: students } \\
\text { from part-time } \\
\text { (Secondary) program, in } \\
\text { Hong Kong }\end{array}$ & $\begin{array}{l}\text { To examine the potential of } \\
\text { using wiki in teacher- } \\
\text { education programs to } \\
\text { develop teachers' abilities. }\end{array}$ & $\begin{array}{l}\text { Content of the } \\
\text { wiki, comments } \\
\text { posted by the } \\
\text { students, } \\
\text { assessments of the } \\
\text { wiki site, self and } \\
\text { peer-assessment, } \\
\text { reflective reports }\end{array}$ & $\begin{array}{l}\text { The students mastered different skills } \\
\text { throughout their collaborative activities } \\
\text { and peer learning such as collaboration, } \\
\text { ICT and organizational skills. Wiki } \\
\text { based activities are useful in developing } \\
\text { a diverse range of teacher capabilities. }\end{array}$ \\
\hline $\begin{array}{l}\text { Liu et al. } \\
(2011)\end{array}$ & $\begin{array}{l}57 \text { third graders ( } 28 \text { in } \\
\text { hypermedia group and } \\
29 \text { linear group) from a } \\
\text { suburban elementary } \\
\text { school in Taipei. }\end{array}$ & $\begin{array}{l}\text { To investigate how } \\
\text { hypermedia and linear } \\
\text { approaches influence the } \\
\text { collaborative learning } \\
\text { experience. }\end{array}$ & $\begin{array}{l}\text { Pre-questionnaire, } \\
\text { questionnaire, } \\
\text { activity logs, } \\
\text { Camtasia. }\end{array}$ & $\begin{array}{l}\text { Performance of students in the } \\
\text { hypermedia group was superior to that } \\
\text { of members in the linear group. }\end{array}$ \\
\hline $\begin{array}{l}\text { Woo et al. } \\
(2011)\end{array}$ & $\begin{array}{l}38 \text { Year-5 students from } \\
\text { Chinese primary schools } \\
\text { and their English } \\
\text { teacher. }\end{array}$ & $\begin{array}{l}\text { To explore the challenges and } \\
\text { benefits of wiki for students } \\
\text { and teachers. } \\
\text { To examine how the } \\
\text { affordances might scaffold } \\
\text { students in the collaborative } \\
\text { writing projects. }\end{array}$ & $\begin{array}{l}\text { Questionnaire, } \\
\text { semi-structured } \\
\text { interview, } \\
\text { focus-group } \\
\text { discussions, } \\
\text { recording. }\end{array}$ & $\begin{array}{l}\text { The use of wiki was perceived } \\
\text { positively and wiki was interesting for } \\
\text { students. In general, wiki helped foster } \\
\text { teamwork and improved writing. }\end{array}$ \\
\hline
\end{tabular}

\section{REFERENCES}

[1] Alagoa, L., \& Roberts, T. (2006). Writing policy. Retrieved February 25, 2011, from http://www.gascoigne.bardaglea.org.uk/documents/WritingPolicy.

[2] Chao, Y. C. J., \& Lo, H. C. (2009). Students' perception of wiki-based collaborative writing sfor learners of English as a foreign language. Interactive Learning Environment, 1, 1-17.

[3] Coniam, D., \& Kit, M.L.W. (2008). Incorporating wikis into the teaching of English writing. Hong Kong Teachers' Centre Journal, 7. Retrieved February 23, 2010, from http:// edb.org.hk/hKTC/download/journal/j7/(5)HKTCJ07-Article2-1.pdf

[4] Creswell, J. (1994). Research design qualitative and quantitative approaches. Thousand Oaks: Sage publications.

[5] Désilets, A., \& Paquet, S. (2005). Wiki as a tool for web-based collaborative storytelling in primary: A case Study. Paper presented at the World Conference on Educational Multimedia, Hypermedia and Telecommunications. Montréal, Québec, Canada. Retrieved July 7, 2010, from http://nparc.cisti-icist.nrc-rc.gc.ca/npsi/ctrl

[6] Ebersbach, A., Glaser, M., Heigl, R., \& Alexander, W. (2008). Wiki web collaboration. (2 ${ }^{\text {nd }}$ ed.). Berlin, Germany: Springer.

[7] Ebner, M., Kickmeier-Rust, M., \& Holzinger, A. (2008). Utilizing wiki-systems in higher education classes: A chance for universal access? Universal Access in the Information Society, 7(4), 199-207.

[8] Ellis, R. (1997). Understanding second language acquisition. Oxford: Oxford University Press.

[9] Elola, I., \& Oskoz, A. (2010). Collaborative writing: Fostering foreign language and writing conventions development. Language Learning and Technology, 14(3), 51-71. 
[10] Engestrom, Y. (1987). Learning by expanding: An activity - theoretical approach to developmental research. Helsinki: Orientakonsultit.

[11] Franco, C.P. (2008). Using wiki-based peer-correction to develop writing skills of Brazilian EFL learners. Novitas-Royal, 2(1), 49-59.

[12] Goodwin-Jones, R. (2005). Blogs and wikis: Environments for on-line collaboration. Language Learning and Technology, 7(2), $12-16$.

[13] Guzdial, M., Rick, J., \& Kehoe, C. (2001). Beyond adoption to invention: Teacher-created collaborative activities in higher education. The Journal of the Learning Sciences, 10, 265-279.

[14] Higgins, L., Flower, L., \& Petraglia, J. (1992). Planning text together.The role of critical reflection in students' collaboration. Written communication, 9(1), 48-84.

[15] Hu, G. (2005). Using peer review with Chinese ESL student writers. Language Teaching Research, 9(3), 321-342.

[16] Kaptelinin, V., \& Nardi, B. A. (2006). Acting with technology: Activity theory and interaction design. Cambridge, MA and London: MIT Press.

[17] Kellogg, R. T. (2001). Long-term working memory in text production. Memory and Cognition, 43-52.

[18] Kessler, G. (2009). Student-initiated attention to form in wiki-based collaborative writing. Language Learning and Technology, 13(1), 79-95.

[19] Knobel, M., \& Lankshear, C. (2008). Remix: the art and craft of endless hybridization. Journal of Adolescent and Adult Literacy, 52(1), 22-33.

[20] Kovacic, A., Bubas, G., \& Zlatovic, M. (2007). Evaluation of activities with a wiki system in teaching English as a second language. International Conference on ICT for Language Learning, Florence, Italy. RetrievedOctober30,2010, from http://www.leonardo-lets.net/ict/common/download/AndrejaKovacic.pdf.

[21] Kuteeva, M. (2011). Wikis and academic writing: Changing the writer-reader relationship. English for Specific Purposes, 30, 44-57.

[22] Lai, Y.C., \& Ng, E.M.W. (2011). Using wikis to develop student teachers' learning, teaching, and assessment capabilities. The Internet and Higher Education, 14(1), 15-26.

[23] Lamb, B. (2004). Wide open spaces: Wikis, ready or not. Educause Review, 39(5), 36-48.

[24] Lin, H. P. (2005). Online collaborative writing with wiki technology: A pilot study. International conference onelearning.RetrievedMarch,22,2009, from http://learning.edu.tw/conference/2005IceL/paper_paper/E002/E5.pdf

[25] Lin, C.H., Li, L. Y., Hu, W. C., Chen, G.D., \& Liu, B. J. (2007). Constructing an authentic learning community through wiki for advanced group collaboration and knowledge sharing. Seventh IEEE International Conference on Advanced Learning Technologies. ICALT, 342-344.

[26] Liu, C. C., Liu. K. P., Chen, W. H., Lin, C. P., \& Chen, G. D. (2011). Collaborative storytelling experiences in social media: Influence of peer-assistance mechanisms. Computers \& Education, 57(2), 1544-1556.

[27] Lund, A. (2008). Wikis: A collective approach to language learning. ReCALL, 20(1), 35-54.

[28] Ma, W.W.K., \& Yuen, A.H.K. (2008). A qualitative analysis on collaborative learning experience of student journalists using wiki. Lecture Notes in Computer Science, 5169, 103-114.

[29] Mak, B., \& Coniam, D. (2008). Using wikis to enhance and develop writing skills among secondary school students in Hong Kong. System, 36(3), 437-455.

[30] Moreno, N. (2009). The use of wikis in the writing of branching stories in a foreign language class. Research, reflections and innovations in Integrating ICT in Education. Retrieved August 17, 2010, from http:// www. Formatex.org/micte2009/book/304308.pdf

[31] Neumann, D. L., \& Hood, M. (2009). The effects of using a wiki on student engagement and learning of report writing skills in a university statistics course. Australasian Journal of Educational Technology, 25(3), 382-398.

[32] Ratcliff, J. (2007). Essay writing guide. Retrieved February 25, 2011, from http:// www.jratcliffe.net/papers/essaywriting.pdf

[33] Storch, N. (2005). Collaborative writing: Product, process, and students' reflections. Journal of Second Language Writing, 14(3), 153-173.

[34] Turgut, Y. (2009). EFL learners' experience of on line writing by PB Wiki. In proceedings of World Conference on Educational Multimedia, Hypermedia and Telecommunications, 3838-3847. Retrieved March 22, 2010, from http:// www.editlib.org.aupac.lib. athabascau.ca/p/32033.

[35] Wang, H., Lu, C., Yang, J., Hu, H., Chiou, G, Chiang, Y., \& Hsu, W. (2005). An empirical exploration of using wiki in an English as a second language course. Proceedings of the Fifth IEEE International Conference on Advanced learning Technologies-ICALT, '05, 155-157.

[36] Woo, M., Chu, S., Ho, A., \& Li, X. (2011). Using a wiki to scaffold primary-school students' collaborative writing. Educational Technology and Society, 14(1), 43-54.

[37] Xiao, Y., \& Lucking, R. (2008). The impact of two types of peer assessment on students' performance and satisfaction within a wiki environment. Internet and Higher Education, 11, 186-193.

[38] Zammit, K. (2010). Working with wikis: Collaborative writing in the 21st century. International Federation for Information Processing. IFIP Advances in Information and Communication Technology, 324, 447-455.

Shokoufeh Ansarimoghaddam is currently a Ph.D candidate at Universiti Putra Malaysia. Her research interests include online and face-to-face collaborative writing, interactive learning environments and Web 2.0 for teaching and learning. 
Bee Hoon Tan $(\mathrm{PhD})$ is Associate Professor at Universiti Putra Malaysia. Her research interests are in language learning technology and learner support. Her recent publication includes two co-edited books and several book chapters and journal papers. Currently she is the chief editor of The English Teacher and an editor of the PERTANIKA JSSH.

Mei Fung Yong (phD) is Senior Lecturer in the Department of English at Universiti Putra Malaysia. Her research interest is in collaborative writing among ESL and EFL learners examining the group dynamics and interactions as well as factors that promote or hinder the process.

Zalina Mohd Kasim (phD) is Senior Lecturer in the Department of English at Universiti Putra Malaysia. 